\title{
The Employment Status of Doctoral Recipients: An Exploratory Study in the Netherlands
}

\author{
Rens van de Schoot \\ Department of Methods and Statistics, Utrecht University, \\ Utrecht, the Netherlands, and Optentia Research Program, \\ North-West University, Vanderbijlpark, South Africa \\ a.g.j.vandeschoot@uu.nl \\ Mara Yerkes \\ Institute for Social Science Research, University of Queensland. \\ Brisbane, Australia, and Erasmus University Rotterdam, \\ Rotterdam, the Netherlands \\ m.yerkes@uq.edu.au \\ Hans Sonneveld \\ Netherlands Centre for Graduate and Research Schools, \\ Utrecht University, Utrecht, the Netherlands \\ j.f.m.sonneveld@uu.nI
}

\begin{abstract}
Material published as part of this publication, either on-line or in print, is copyrighted by the Informing Science Institute. Permission to make digital or paper copy of part or all of these works for personal or classroom use is granted without fee provided that the copies are not made or distributed for profit or commercial advantage AND that copies 1) bear this notice in full and 2) give the full citation on the first page. It is permissible to abstract these works so long as credit is given. To copy in all other cases or to republish or to post on a server or to redistribute to lists requires specific permission and payment of a fee. Contact Publisher@InformingScience.org to request redistribution permission.
\end{abstract}

Studies of employment often focus on general labour market developments or the employment status of vulnerable groups concentrated at the lower end of the labour market. In contrast, the employment of highly educated individuals, in particular $\mathrm{PhD}$ recipients, has received less empirical attention. This article contributes to this area using data from a web survey carried out among respondents at four universities in the Netherlands. Dutch doctoral recipients have an above-average employment rate of 86 per cent. In addition, when looking at variables related to academic and non-academic employment, demographic variables, such as age and children living in the household, as well as publications submitted and accepted, are more closely related to contract type (permanent versus temporary) than factors such as $\mathrm{PhD}$ supervision and labour market preparation. Gender is a particularly important variable related to employment status, with male doctoral candidates more likely to be employed outside academia. We conclude with recommen-

dations for PhD candidates, their supervisors and universities.

Keywords: employment outcomes, employment rate, gender differences, labour market status, research experience and individual performance, Netherlands, doctoral degrees. 


\section{Introduction}

In recent years, the labour market status of $\mathrm{PhD}$ recipients has been a continued subject of interest in both the Netherlands and abroad. For example, most Western countries are concerned with competing globally with a strong knowledge society, whereby highly-educated workers play a vital role. In the Netherlands, there is a clear focus on improving the knowledge society, including the explicit ambition to be in the top five of knowledge societies globally, which the government feels requires a strengthening of education and an improvement of performance at the top level (Ministry of General Affairs, 2010). Doctoral education is an important factor in this regard, contributing to the development of the nation's research capacity and generating a highlyeducated workforce. Previous studies in the Netherlands (Hulshof, Verrijt, \& Kruijthoff, 1996; Van der Neut \& de Jonge, 1993) have focused on the added value of a PhD (in comparison to a master's degree) with respect to employment outcomes. There has also been attention in the Netherlands for the expectations recent postdoctoral researchers have regarding their career prospects, in particular opportunities to continue their research within academia (Hoffius \& Surachno, 2006). Thus far, the study by Hulshof et al. (1996) is the most comprehensive and theoretical study of the situation in the Netherlands. Over the years that followed, no new studies were conducted on the labour market status of Dutch PhD recipients until 2006, when Oost and Sonneveld (2006) reported on the data disclosed by Dutch research and graduate schools about the labour market prospects of their PhD recipients. Again in 2006, and following up on European initiatives, Hersevoort, Rienstra, and Ter Haar (2007) conducted a preliminary exploration of the employment status or graduate destinations of $\mathrm{PhD}$ recipients residing in the Netherlands. As a result, research on the labour market status of $\mathrm{PhD}$ recipients in the Netherlands is fragmented. The lack of research in this area is in part due to an absence of data. Neither Dutch universities nor the Dutch Ministry of Education, Culture, and Science have a policy of conducting periodic surveys to evaluate the employment status of $\mathrm{PhD}$ recipients. This absence is surprising, given the desire to improve the position of the Dutch economy by further developing the knowledge economy.

The absence of structural data collection from these groups contrasts sharply with standard practices in the United States, for example, where data on doctorate recipients has regularly been collected since the 1950s. The Survey of Earned Doctorates has been carried out since 1957, which

gathers information on all individuals receiving a doctorate from a US-accredited institution. Data collected includes information on socio-economic characteristics, educational trajectories, and post-education plans. More recently, the UK and Australia have conducted surveys on doctoral recipients as well (Manathunga, Pitt, \& Critchley, 2009; UK Grad Programme, 2004), showing increased international attention for the employment status of doctoral recipients. In fact, the lack of comparable data on $\mathrm{PhD}$ graduates, for example on doctorate holders and employment outcomes, led the Organisation for Economic Cooperation and Development (OECD), the United Nations Educational, Scientific, and Cultural Organisation (UNESCO) and the European Union's statistical organisation EUROSTAT to advocate an internationally coordinated collection of data about the career paths of PhD recipients in Europe (EUROSTAT / UNESCO / OECD, 2006).

Given the lack of comparable data, the majority of studies that do investigate educational or employment outcomes for $\mathrm{PhD}$ graduates often focus on specific areas, such as specific fields of study, including economics (Siegfried \& Stock, 1999), sociology (Dotzler \& Koppel, 1999), history (Sclater, Rudd, Morrison, Picciano, \& Nerad, 2008), science and engineering (Lee, Miozzo, \& Laredo, 2010) or the biomedical sciences (Knobil, 1996). Another group of studies are focused on specific topics, such as studies on gender (Mastekaasa, 2005; NRC, 2010), academic employment and mobility (J. Enders, 2001; Huisman, de Weert, \& Bartelse, 2002; Musselin, 2004) or doctoral training (Bleiklie \& Høstaker, 2004; J. Enders \& de Weert 2004). Finally, a number of country-specific studies are available, including Finland (Academy of Finland, 2003), the US (Nerad, 2004), France (Dany \& Mangematin, 2004) and the UK (UK Grad Programme, 2004). 
Only recently has more attention been given to creating comprehensive studies of doctoral trajectories (Sadlak, 2004).

Until comparable data across all fields of study is available, our knowledge of the employment trajectories of $\mathrm{PhD}$ recipients remains limited. We address this lacuna by presenting information on the employment outcomes and major correlates of these outcomes for $\mathrm{PhD}$ recipients at four universities in the Netherlands.

\section{Research Questions}

The current article answers two research questions. First, what is the existing labour market position of doctoral recipients at the time of graduation in the Netherlands? Second, what factors influence the initial labour market position of recent doctoral recipients in the Netherlands? The first question is aimed at increasing our knowledge about the employment status of $\mathrm{PhD}$ recipients. An article by Fox and Stephan (2001) finds, for example, that career preferences of $\mathrm{PhD}$ recipients vary by gender and field of study. We also know from previous research in the Netherlands that academic employment is a well-trodden career path for many doctoral recipients, with $\mathrm{PhD}$ graduates and postdoctoral researchers often preferring to continue their careers in academia (Hoffius \& Surachno, 2006; Keijzer \& Gordijn, 2000). This preference has been attributed to a high level of job satisfaction, in particular due to flexible working hours, intellectual stimulation, and a high degree of independence in their job. However, both $\mathrm{PhD}$ graduates and postgraduate researchers hold negative perceptions about their career opportunities in academia, in part due to the initial period of employment consisting of numerous temporary contracts (Hoffius \& Surachno, 2006). To account for possible diversity in employment outcomes, we analyse, on the one hand, whether doctoral recipients go on to academia or to employment in the private sector and, on the other hand, whether graduates are employed in temporary or permanent positions.

The second question is focused on increasing our understanding about which factors correlate with these employment outcomes. According to previous studies, several indicators affecting employment outcomes reflect the quality of the $\mathrm{PhD}$ program and labour market preparation: integration into the academic community (also internationally; see Bowen \& Rudenstine, 1992; Golde, 2000); sound management of the PhD trajectory (by the thesis supervisor, as well as by the PhD candidate) (Berger \& de Jonge 2005; Bowen \& Rudenstine, 1992; Hockey 1991; Oost \& Sonneveld, 2006; Rennie \& Brewer, 1987); broad scope of the program (benefiting labour market versatility) (Bowen \& Rudenstine, 1992; Hills, Robertson, Walker, Adey, \& Nixon, 2003); promotion of academic independence (direction from thesis supervisors, for example) (Bowen \& Rudenstine, 1992; Lovitts, 2008; Rennie \& Brewer, 1987); and quality of preparation for the labour market (through career information, for example, or support provided for developing future research proposals) (Austin, 2002; Bowen \& Rudenstine, 1992; Oost \& Sonneveld, 2006). However, because the research on factors related to employment outcomes is relatively limited, we include not only variables aimed at measuring the quality of the $\mathrm{PhD}$ program and labour market preparation (such as expectations of the $\mathrm{PhD}$ recipients, and $\mathrm{PhD}$ supervision and career guidance) but also a wide range of other possible correlates, including demographic variables, $\mathrm{PhD}$ status, previous research experience, and individual performance characteristics.

The remainder of the article is structured as follows. In the next section, we discuss our data and methodology. In section three, we present the results of our empirical analysis, looking at the correlations between demographic characteristics, the $\mathrm{PhD}$ trajectory as well as supervision and labour market preparation with permanent and temporary employment, both inside and outside academia. In the final section, we discuss these results and make some suggestions for future research directions. 


\section{Data and Methodology}

\section{Data and Sampling Procedure}

The data presented here are the results of a web survey carried out among respondents at four universities in the Netherlands (Delft University of Technology, Erasmus University Rotterdam, Utrecht University, and Wageningen University and Research Centre) between February 2008 and June 2009 (see also Yerkes, van de Schoot, \& Sonneveld, 2012). These four universities were used because they are representative of the broader variety of universities in the Netherlands, including a younger university with a more limited disciplinary agenda (Rotterdam), a university focused on the agricultural sciences (Wageningen), a more traditional university with a broad disciplinary agenda (Utrecht), and a university focused on the technical sciences (Delft). The respondents for this survey were approached through the Registrar's office of the university, in charge of organising the doctoral defence following registration for graduation. We then e-mailed respondents, inviting them to take part in the survey. Respondents were approached a maximum of three times, including reminder e-mails. All of the information collected in this survey, including the e-mail addresses gathered at the start of the research, remains confidential. All variables that contained personal information, such as name and address, name of supervisor, or any other personal identification have been removed for purposes of confidentiality.

As noted in Yerkes et al. (2012), survey respondents were surveyed at the moment of registering for the defence and therefore may be perceived by some to not yet be doctoral recipients. However, the structure of the Dutch system significantly differs from other countries. PhD candidates are most often employed as full-time researchers at the university during the completion of their doctorate, a distinction discussed further in the next section. Also, the Dutch system lacks ABD status (i.e., all but dissertation) and registering for the defence is only allowed following official approval of the doctoral thesis by the defence committee. Outside of exceptional cases such as fraud, the degree will be conferred following a primarily ceremonial defence. For these reasons, the participants in our study are referred to as doctoral recipients.

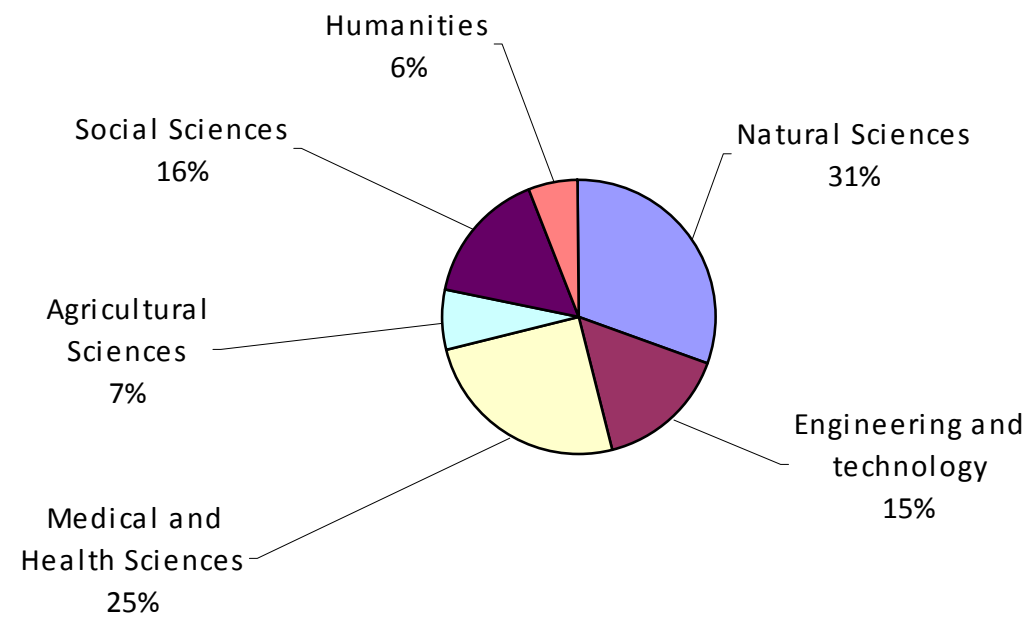

Figure 1. Percentages of field of study

The sampling frame consisted of $1113 \mathrm{PhD}$ candidates who registered for their defense between February 2008 and June 2009 at the four universities studied. Just over half of those candidates approached agreed to participate in the study and completed the survey. The overall response rate was $50.7 \%$ with a survey sample of 565 respondents. The survey sample consists of $54 \%$ men, 
$46 \%$ women and includes respondents from all disciplines, see Figure 1. The mean age of our respondents was 34 years old with the majority between the ages of 25 and 40 . Some graduates were over the age of 40 when reaching the completion stage of their doctorate: Two-thirds of doctoral recipients surveyed were born in the Netherlands (67\%).

Doctoral recipients born in other countries were most often born in other Western European countries, Asian countries, or Eastern European countries. Less than five per cent of doctoral recipients surveyed were from North America, Latin and South America or Africa.

\section{Measures}

In the analyses to follow, individual level differences are accounted for using demographic variables, variation in $\mathrm{PhD}$ trajectories and the effects of $\mathrm{PhD}$ supervision and labour market preparation.

\section{Demographic variables}

The following demographic variables are included: marital status, the presence of children in the household, nationality/citizenship, gender, and age. Marital status is measured with a dummy variable: the reference category is never married/divorced/widowed/separated; the category of married or cohabitating $=1$. We also estimated the effect of the presence of children in the household (no children present is the reference category). Given the complexity of nationality, we used three different variables here, including whether or not an individual came to the Netherlands to obtain their $\mathrm{PhD}$ or for some other reason, whether an individual has Dutch citizenship or not, and whether or not the individual is living in the Netherlands at the time of the defence. The first variable measured whether or not an individual came to the Netherlands to obtain their $\mathrm{PhD}$. The citizenship variable measured whether or not an individual has a Dutch passport. Living in the Netherlands at the time of the defence is a dummy variable (a country other than the Netherlands is the reference category). Gender is measured with a dummy variable (female is the reference category). Lastly, we measured age in years.

\section{PhD status}

In the Netherlands it is possible to differentiate between three different types of $\mathrm{PhD}$ status (see also Yerkes et al., 2012), including (a) a PhD candidate employed by the university, (b) scholarship recipients, and (c) external and/or dual $\mathrm{PhD}$ candidates. Full employment contracts for $\mathrm{PhD}$ candidates are the exception and not the rule throughout Europe. Only the Netherlands, Finland, and Turkey have doctoral educational structures in which different types of PhD status exist simultaneously (EC, 2007). In the Netherlands, PhD candidates with the status of employee are covered by an employment contract, which specifies working conditions and salary based on a collective agreement covering the Association of Universities in the Netherlands (see www.vsnu.nl for more information). Scholarship recipients do not have an employment contract. Rather, they are given a scholarship or stipend for a specified period of time. Lastly, external and/or dual PhD candidates, often not accounted for in studies on doctoral education in the Netherlands, are an amalgamation. These $\mathrm{PhD}$ candidates do not have a formal $\mathrm{PhD}$ contract at the university, nor do they have a scholarship or stipend. Their status can take on different forms, for example an external candidate who works part-time on his or her $\mathrm{PhD}$ thesis while having a job elsewhere, or dual candidates, such as junior lecturers who work part-time at a university while working part-time on their $\mathrm{PhD}$ thesis. There are also a number of external candidates who work on their PhD thesis during retirement. Throughout this article, these three forms are referred to as (1) employees, (2) scholarship recipients, and (3) external candidates. The majority of respondents surveyed (71.1\%) reported that their main formal status was 'employee' with five per cent listing 'scholarship recipient' as their main $\mathrm{PhD}$ status. The share of external or dual $\mathrm{PhD}$ candi- 
dates was 23.9 per cent. The number of scholarship students in our sample is too small to be included in the analyses here. Therefore, we distinguished between PhD candidates employed by the university (the reference category) and external candidates. PhD status was included as a control variable in our analyses.

\section{Previous research experience}

Research experience was measured as whether or not an individual gained research experience prior to commencing the doctoral trajectory and, if so, the number of years of research experience. We note that the variable measuring years of research experience did not have a standard distribution and was therefore included in the model as a count variable with a Poisson distribution. In other words, nearly all respondents have a zero (no years of research experience) yet the answers provided by respondents who do not have a zero are distributed normally. Mplus accounts for this zero-inflated variable, using a mixture approach in the analyses, which results in two parameters: (1) an intercept and mean score for no experience versus experience and (2) a regression coefficient for the non-zeros.

\section{Individual performance characteristics}

These were measured in terms of publications, expectations in regards to publications, and entrepreneurship. Publication variables included the number of submitted and accepted international, scientific journal articles. We also included (1) whether or not respondents had individual expectations of how much scientific output they expect to produce (i.e., the number of papers/book chapters), (2) how much scientific output their supervisor expected them to produce, and (3) how much scientific output their research school or institute expected them to produce.

\section{Effect of PhD supervision and career guidance}

In the survey, we asked $\mathrm{PhD}$ candidates to respond to a series of statements regarding $\mathrm{PhD}$ supervision and career guidance. We did this based on the assumption that the quality of the $\mathrm{PhD}$ program (including supervision) and labour market preparation could be related to educational and employment outcomes of PhD recipients. Respondents were presented with 29 statements related to the $\mathrm{PhD}$ trajectory and labour market preparation. Responses were measured on a five-point Likert scale, varying from 1 "completely agree" to 5 "completely disagree." The lower the average score, the more respondents agreed with the statement.

These statements were combined to form nine scales measuring (1) the role of the supervisor in creating the PhD candidate's network, (2) the role of the supervisor in supporting and preparing the $\mathrm{PhD}$ candidate for the labour market, (3) the PhD candidate's insight into the necessary steps to be taken during the research trajectory, (4) the quality of supervisory guidance in writing and finishing the $\mathrm{PhD}$ thesis, (5) the versatility of the educational trajectory (in terms of subjects studied and extra study and research possibilities) and labour market preparation, (6) the intensity of contact with other $\mathrm{PhD}$ candidates (preventing isolation during the $\mathrm{PhD}$ trajectory), (7) the quality of preparatory labour market information provided for by the supervisor/graduate school/university, (8) individual responsibility of the $\mathrm{PhD}$ candidate in finding a job following graduation, and (9) research experience abroad and support in obtaining international research funding post-PhD. These scales were created using confirmatory factor analysis, using Mplus 5.21 (Muthén \& Muthén, 2007). Full maximum likelihood estimation was used to deal with missing items. Fit indices indicated a moderate fit $(\mathrm{CFI}=.90 ; \mathrm{TLI}=.88 ; \mathrm{RMSEA}=.04 ; \mathrm{SRMR}=.06$; $\mathrm{n}=413)$. 


\section{Analysis}

The analysis consists of two parts. The first research question is answered using descriptive statistics. Note that in the current paper, all available information about our respondents is used. No data have been imputed through missing analysis for the descriptive information, which explains why the sample size does not equal 565 for some of the results.

The analyses presented for the second research question are based on logistic regression models carried out in Mplus v.5.21 (Muthén \& Muthén, 2007). We included respondents with missing data in the model estimations using full information maximum likelihood estimation because missing data were completely at random (C. K. Enders \& Bandalos, 2001). We began the analyses by looking at having a permanent or temporary contract, broken down into academic and nonacademic employment. The analyses used to answer the second research question consisted of three analytical steps: (1) the relationship between demographic characteristics and employment status, (2) the relationship between previous research experience, academic performance, $\mathrm{PhD}$ status and employment status, and (3) the relationship between $\mathrm{PhD}$ supervision, labour market preparation, the quality of the educational trajectory, and employment status. Note that the latter model is a hybrid model, where the latent variables of the measurement model of the questionnaire are used to predict employment status.

The results of our analyses are reported in odds ratios. We only report the odds ratios and significance values for space reasons. The full results, including standard errors and p-values can be obtained from the authors upon request. A simple way to interpret the findings in the tables is to consider whether the odds ratio differs from one, not zero. For example, if we compare men and women and the likelihood of having a permanent contract, an odds ratio of 1 would mean there are no differences between men and women for the likelihood of having a permanent contract, whereas an odds ratio of three would mean that men are three times more likely than women to have a permanent contract. Odds ratios of less than one, for example, an odds ratio of 0.3 , would mean women are 1/0.3 times more likely to have a permanent contract than men. Statistical significance is reported as follows: $*=\mathrm{p}$-value $<.10 ; * *=\mathrm{p}$-value $<.05 ; * * *=\mathrm{p}$-value $<.01$.

\section{Results}

\section{The Current Employment Status of Doctoral Recipients}

We start by describing the initial labour market status of recent doctoral recipients in the Netherlands in our sample. Looking at employment at the time of graduation, the existing data demonstrate that the employment rate of Dutch doctoral recipients is relatively high; 86 per cent of doctoral recipients in the sample surveyed are in employment at the moment of the defence, see Table 1 (see also Sonneveld, Yerkes, \& Van de Schoot, 2010; Yerkes et al., 2012). Another nine per cent of respondents are not working, three per cent of respondents are not seeking a job, and two per cent of respondents answered 'don't know', for example, because they were taking a period of time off at the time of graduation. On average, recent doctoral recipients report having a contract for 38 hours a week, not taking into account possible overtime hours. We can compare the results from our sample with a sample of recent doctorate holders from a Statistics Netherlands (2011) study, looking at the 2009 employment status of doctorate recipients from 2008. Of the 1,400 recent $\mathrm{PhD}$ recipients in the Statistics Netherlands study, 7 per cent were unemployed or inactive (i.e., not looking for a job). 
Table 1: Employment Status and PhD Status $(n=478)$

\begin{tabular}{lrrrr}
\hline & Aio & $\begin{array}{r}\text { Scholarship } \\
\text { recipient }\end{array}$ & $\begin{array}{r}\text { External PhD } \\
\text { candidate }\end{array}$ & Total \\
\hline $\begin{array}{l}\text { Working full-time, or have/had accepted a full- } \\
\text { time job offer }\end{array}$ & $220(64.5)$ & $16(61.5)$ & $73(65.8)$ & $309(64.6)$ \\
Working full-time but seeking a different job & $28(8.2)$ & $3(11.5)$ & $7(6.3)$ & $38(7.9)$ \\
Working part-time but seeking full-time work & $12(3.5)$ & $0(0.0)$ & $4(3.6)$ & $16(3.3)$ \\
Working part-time but NOT seeking full-time & $24(7.0)$ & $0(0.0)$ & $13(11.7)$ & $37(7.7)$ \\
work & & & & \\
Working full-time or part-time in more than one & $7(2.1)$ & $1(3.8)$ & $3(2.7)$ & $11(2.3)$ \\
job & $22(6.5)$ & $2(7.7)$ & $1(0.9)$ & $25(5.2)$ \\
Not working but seeking full-time work only & $1(0.3)$ & $0(0.0)$ & $1(0.9)$ & $2(0.4)$ \\
Not working but seeking part-time work only & $15(4.4)$ & $0(0.0)$ & $2(1.8)$ & $17(3.6)$ \\
Not working but seeking any work (Full-time or & & & & \\
part-time) & $4(1.2)$ & $0(0.0)$ & $0(0.0)$ & $4(0.8)$ \\
Not working and unavailable for study or paid & $2(0.6)$ & $2(7.7)$ & $5(4.5)$ & $9(1.9)$ \\
work & $6(1.8)$ & $2(7.7)$ & $2(1.8)$ & $10(2.1)$ \\
Not working and unavailable for paid work & $341(100.0)$ & $26(100.0)$ & $111(100.0)$ & $478(100.0)$ \\
Don't know & & & & \\
Total & & &
\end{tabular}

The employment rate among Dutch doctoral recipients in our sample is much higher than in the general Dutch working population. According to Statistics Netherlands, the employment rate for 15 to 64 year-olds was 68 per cent in 2008 (CBS, 2010). After accounting for educational level, our sample is three per cent higher than the employment rate for persons in the Dutch population with a higher educational level. Of all persons with at least a university education in the Netherlands, 83 per cent are currently employed (CBS, 2010). Unemployment rates are even lower among doctorate holders. A study from Statistics Netherlands (2011) of the situation in 2009 shows that out of a total of 43,100 doctorate holders, 41,000 were employed, 600 were unemployed, and 1,500 were inactive and not seeking employment. In sum, 4.9 per cent of Dutch doctoral holders were unemployed or inactive in 2009. These figures include individuals up to 69 years old; with a retirement age of 65 , it is possible that a small, but minor share of the unemployed or inactive doctoral holders are retired individuals. In general, though, results from our sample are in line with earlier data from Hulshof, Verrijt, and Kruijthof (1996), which demonstrate that unemployment has remained unproblematic for most doctoral recipients as most are already employed at the time they finish their $\mathrm{PhD}$ thesis.

Doctoral recipients in the Netherlands follow numerous career paths (see Table 2). 28 per cent of respondents indicated they were employed at a Dutch university following graduation. However, if we include Dutch university-affiliated medical centres, hospitals, and research institutes, this number rises to more than 50 per cent. Nearly 12 per cent of recent doctoral recipients are employed with a foreign university or a university-affiliated organisation abroad. In sum, 63 per cent of the respondents are employed within academia, either in the Netherlands or abroad. These results are similar to findings from Hulshof et al. (1996), who show that in 1996 roughly half of all doctoral recipients were employed at a university or research institute. It is interesting to note that of the six per cent of doctoral recipients who are self-employed (26 respondents), more than half (14 respondents) combine their self-employment with another job and therefore do not report self-employment as their main form of employment. 


\begin{tabular}{lr}
\hline \multicolumn{2}{c}{ Table 2: Type of Employment (n=417) } \\
\hline Type of Employer & $\begin{array}{r}\text { Total Number } \\
\text { (percentage) of } \\
\text { Respondents }\end{array}$ \\
\hline Dutch university & $117(28.1)$ \\
Dutch university-affiliated & $67(16.0)$ \\
hospital or medical centre & \\
Dutch Royal Academy- & $8(1.9)$ \\
affiliated research institute & \\
Dutch university-affiliated re- & $22(5.3)$ \\
search institute & \\
Foreign university & $31(7.4)$ \\
Foreign university-affiliated & $1(0.2)$ \\
hospital or medical centre & \\
Foreign royal academy- & $8(1.9)$ \\
affiliated research institute & \\
Foreign university-affiliated & $8(1.9)$ \\
research institute & \\
Foreign national government & $4(1.0)$ \\
Foreign local government & $1(0.2)$ \\
Dutch national government & $17(4.1)$ \\
Dutch local government & $1(0.2)$ \\
Not for profit organisation & $29(7.0)$ \\
Industry or business (for & $63(15.1)$ \\
profit) & \\
Self-employed & $13(3.1)$ \\
Other - Specify & $6(1.4)$ \\
Non-academic hospital & $6(1.4)$ \\
Non-academic research insti- & $15(3.6)$ \\
tute & \\
Total & $417(100.0)$ \\
\hline &
\end{tabular}

Looking at our sample, a total of 17 per cent of recent doctoral recipients continue to be employed in some form of professor position following graduation (14 per cent as assistant professor, two per cent as associate professor, and one per cent as professor). 12 per cent of respondents who did not list a faculty rank (faculty rank not applicable, don't know, or 'other') report an academic position of research faculty or scientist. A further eight per cent of respondents who did not list a faculty rank are employed in a medical profession within academia.

The majority of doctoral recipients (66.1\%) are primarily concerned with (applied) research in their first job reported at the time of the defence. A smaller percentage of respondents are primarily concerned with development activities $(8 \%)$ or professional services $(8 \%)$. Another 10 per cent of respondents report that teaching is the activity they spend the most time on. According to our survey, 88 per cent of all doctoral recipients in the Netherlands now perform work that is in some way related to their $\mathrm{PhD}$.

While there is a high rate of employment among Dutch doctoral recipients, 49 per cent of our respondents answered that they have a job that is in some way not permanent. This rate of temporary employment represents an increase in temporary contracts under doctoral recipients. In 1996, two-thirds of doctoral recipients had a permanent contract (Hulshof et al., 1996), whereas this percentage has now decreased to 51 per cent. 
Within this category of respondents working on a temporary contract, 76 per cent of them are working at a university. Only 24 per cent of doctoral recipients working on a temporary contract are employed outside the university. However, the permanency of employment is significantly related to the PhD status of doctoral candidates (see Table 3; Chi-square $=58.144 ; 2 \mathrm{DF} ; \mathrm{p}<.001$; $\mathrm{n}=404$ ). In total, 79 per cent of external candidates are employed under a permanent contract, whereas only 35 per cent of $\mathrm{PhD}$ candidates who had the status of employee have a permanent contract following graduation.

Again, we compared our results with those of Statistics Netherlands (2011). According to Statistics Netherlands (2011), 2,700 individuals were awarded a doctorate degree in 2008. By 2009, $52 \%$ had a permanent contract versus $48 \%$ on a temporary contract. The proportion of permanent contract holders increases among older cohorts of doctoral recipients. Just over two-thirds (68\%) of doctoral recipients from 2004 have a permanent contract and 79\% of the total population of employed, Dutch doctoral holders (from 1990 onwards) has a permanent contract.

\begin{tabular}{lcrr}
\hline \multicolumn{4}{c}{ Table 3: Number (Percentage) of Graduates with Permanent and Temporary Contracts, } \\
by PhD Status (n=404)
\end{tabular}

\section{Variables Correlated With Employment Status}

We considered the employment status of doctoral recipients in two ways. On the one hand, we are interested in whether doctoral recipients go on to academia or to employment outside academia. On the other hand, we want to know whether graduates are employed in temporary or permanent positions. Note that we only consider employees and external PhD candidates in this part of the analyses due to the small sample size of scholarship recipients.

Table 4: Number (Percentage) of Doctoral Candidates in Academic vs. Non-academic Employment and Permanent vs. Temporary Employment $(n=386)$

\begin{tabular}{rccr}
\hline Contract type & University employer & Non-university employer & Total \\
\hline Permanent & $89(34.6)$ & $85(65.9)$ & $174(45.1)$ \\
In some way not permanent & $168(65.4)$ & $44(34.1)$ & $212(54.9)$ \\
total & $257(100)$ & $129(100)$ & $386(100)$ \\
\hline
\end{tabular}

The strongest correlation can be found between university employment and temporary contracts. Looking at Table 4, we see that 65 per cent of respondents who are employed within a university setting do not have a permanent contract, against 34 per cent of respondents who are employed in a non-university setting with a non-permanent contract. There is a significant relationship between these two aspects of employment (Chi-square $=33.093(1 \mathrm{DF}) ; \mathrm{p}<.001 ; n=386)$. Given this significant relationship between contract type and academic versus non-academic employment, we continue in our analysis examining differences in the likelihood of having a permanent versus temporary contract, while accounting for differences in academic and non-academic employment. We examined the likelihood of being in non-academic employment (academic employment is the reference category) based first on a combination of demographic factors followed by previous 
research experience, $\mathrm{PhD}$ status and individual performance during the $\mathrm{PhD}$ trajectory and lastly based on the scales measuring labour market preparation, supervision and the educational trajectory.

\section{Demographic Characteristics}

Estimating the effect of demographic characteristics on the likelihood of a permanent contract in both academic and non-academic employment shows that having a child is strongly correlated with having a permanent contract both in academic and in non-academic employment (see Table 5). Doctoral recipients with children are 3.5 times as likely to have a permanent contract outside academia in comparison to doctoral recipients without children; in academic employment they are twice as likely to have a permanent contract. Age is also significantly correlated with having a permanent contract in academia. Lastly, gender is an important factor outside of academia as far as contract type is concerned. Male doctoral recipients have a significantly greater chance of having a permanent contract in comparison to female doctoral recipients in non-academic employment.

Table 5: Likelihood of a Permanent Contract $(n=347)$

\begin{tabular}{lll}
\hline Academic Employment & OR (odds ratio) \\
\hline & Marital Status & 0.902 \\
& Presence of children in the household & $2.185^{*}$ \\
& Living in the Netherlands & 0.672 \\
& Citizenship & 1.076 \\
& Gender & 1.301 \\
& Age & $1.138^{* * *}$ \\
\hline Non-academic Em- & & \\
ployment & & 1.218 \\
& Marital Status & $3.459^{* *}$ \\
& Presence of children in the household & 0.544 \\
& Living in the Netherlands & 1.082 \\
& Citizenship & $3.833^{* *}$ \\
& Gender & 1.035 \\
\hline
\end{tabular}

\section{Previous Research Experience and Individual Performance}

In the next step of the analyses, we measure the correlation between previous research experience, individual performance, and the likelihood of having a permanent contract in academic versus non-academic employment. The results of this analysis are shown in Table 6.

Previous research experience is not significantly correlated with contract type in academic or non-academic employment. Rather, there is a significant relationship between $\mathrm{PhD}$ status and the likelihood of having a permanent contract, both inside and outside academia. Recalling that $\mathrm{PhD}$ status, as measured here, analyses the differences between employees and external $\mathrm{PhD}$ candidates, with employee as the reference category, the results demonstrate that external $\mathrm{PhD}$ candidates are 1.9 times (1.863) more likely to have a permanent contract than employees outside academia. Within academia, external candidates are 2.7 times (2.658) more likely to have a permanent contract. 


\begin{tabular}{lll}
\hline \multicolumn{2}{c}{ Table 6: } & Likelihood of Having a Permanent Contract (n=358) \\
\hline Academic Employment & & OR (odds ratio) \\
\hline & Previous research experience & 1.092 \\
& PhD Status & $2.658^{* * *}$ \\
& Articles submitted & 0.969 \\
& Articles accepted & $1.124^{*}$ \\
& Individual publication expectations & $0.784^{*}$ \\
& Supervisor publication expectations & 1.045 \\
& Institute publication expectations & 1.021 \\
\hline Non-academic Em- & & \\
ployment & & 1.100 \\
& Previous research experience & $1.863^{* *}$ \\
& PhD Status & 0.919 \\
& Articles submitted & 1.132 \\
& Articles accepted & 0.989 \\
& Individual publication expectations & 0.840 \\
& Supervisor publication expectations & 1.042 \\
\hline
\end{tabular}

The only other variables significantly correlated with permanent employment in academia are the number of articles accepted and individual publication expectations. The higher the respondents' own publication expectations are, the lower the likelihood of a permanent contract. Lastly, the higher the number of accepted articles, the higher the likelihood of a permanent contract in academia.

\section{Labour Market Preparation, Supervision and Educational Trajectory}

When measuring the relationship between supervision, career guidance, and the likelihood of permanent or temporary employment both inside and outside academia, we found that most of the scales calculated to measure the effect of these items returned no significant results. In fact, when we control for demographic characteristics, previous research experience, and individual performance, only one scale remained significant while any significance from the other scales was no longer present. We have not included these results for space reasons. The results of both the simplistic model (using the scales as independent variables) and the combined model can be obtained from the authors upon request.

The only significant correlation found was between the quality of supervisory guidance in writing and finishing the PhD thesis and employment status. This variable is negatively correlated with the likelihood of having a permanent contract in academia.

\section{Conclusion}

In this paper, we focused on investigating the current employment status of recent doctoral recipients in the Netherlands at the four Dutch universities studied. We have analysed which factors are correlated with someone working inside or outside academia, as well as the likelihood of having a permanent contract both inside and outside academia. The analyses provide a number of important conclusions.

First, the most important conclusion is that doctoral recipients have an above-average employment rate at the time of graduation: 86 per cent of all doctoral recipients surveyed were em- 
ployed. Moreover, 63 per cent of the respondents were employed within academia, either in the Netherlands or abroad. Nearly half of all graduates were employed under a temporary contract; this reflects an increase in temporary contracts during the past 16 years in the Netherlands (Hulshof et al., 1996). Taking a closer look at employment status, we found three significant correlates of non-academic employment and one significant correlate of academic employment. Gender was significant: male doctoral candidates were one and a half times more likely to be employed outside academia. External $\mathrm{PhD}$ candidates were also more likely to be employed outside academia. Lastly, $\mathrm{PhD}$ candidates who were positive about the role of their supervisor and the way their supervisor prepared them for the labour market were more likely to be employed outside academia.

We also considered the most important correlates of permanent and temporary employment, both inside and outside academia. We find a number of significant correlates of having a permanent contract, including age (inside academia) and the presence of children (both inside and outside academia). External PhD candidates are also more likely to be employed under a permanent contract than employees in academia. In addition, the higher the number of articles accepted for publication, the higher the likelihood of a permanent contract in academia. In sum, in our sample, demographic characteristics, such as age and children living in the household, previous research experience and individual performance, such as publications submitted and accepted, are more important correlates of contract type inside and outside of academia than factors such as supervision and labour market preparation.

\section{Limitations of this Study}

This study produced significant results that inform our understanding of the employment status of doctoral recipients at the time of graduation. Nevertheless, there are some limitations to our study that should be discussed and that can be used to inform further research directions. First, as we only have cross-sectional data from four of the twelve universities in the Netherlands, future studies are necessary that work from a larger, random, and representative sample of Dutch universities. Ideally, $\mathrm{PhD}$ candidates should be followed throughout the $\mathrm{PhD}$ trajectory, allowing for a comprehensive understanding of individual and structural variables affecting education and employment outcomes of doctoral graduates. In addition, qualitative data such as interviews or focus groups with doctoral candidates, university administrators such as Heads of School and/or Deans could provide in-depth information about academic appointments, including the use of temporary contracts and any funding issues affecting such appointments. Research such as this can further inform both government and university policies.

We also note that a number of the conclusions presented here are intriguing but simultaneously confirm the need for more research. In particular, more long-term research on the relationship between the PhD trajectory and employment is needed to put some of these conclusions into perspective. While it is understandable that age is significantly correlated with having a permanent contract, as work experience also increases with age, a number of other results, such as the differences between individuals with and without children or gender differences, raise theoretical and empirical questions that require further investigation. For example, is self-selection evident among parents, that $\mathrm{PhD}$ recipients with children choose private sector employment because of assumed employment contract differences? Did older cohorts of doctoral recipients obtain permanent employment contracts at a time when permanent contracts were more common than today? Is the gender difference in permanent employment outside academia evidence of continued gender differences in employment, even in the highest echelons? Such employment differences between men and women and between younger and older cohorts of doctoral recipients could have important implications for the employment and social security of these groups. To inform these debates, future research would do well to focus on these important questions. 


\section{Recommendations}

Finally, we would like to make a number of recommendations based on our research findings. We focus on three different groups of stakeholders: (1) PhD candidates, since they are the primary concern of this article; (2) $\mathrm{PhD}$ supervisors since they are the main players in the professional lives of $\mathrm{PhD}$ candidates and their role in preparing $\mathrm{PhD}$ candidates for the labour market may be considerable, although in many cases it proves negligible; and (3) last we examine the organisations within which supervisors and $\mathrm{PhD}$ candidates operate: graduate schools, research schools, and the universities encompassing them.

\section{Recommendations for PhD candidates}

Very few $\mathrm{PhD}$ candidates have reason to hope that their supervisors will offer them a job following graduation. As perceived by doctoral recipients, supervisors heavily emphasized that doctoral recipients are responsible for finding their own way in the labour market. Our research suggests that doctoral recipients feel that supervisors provided little useful information about career options, especially outside academia, although they were very active in aspects of academic labour market preparation, emphasizing the importance of publishing in international, scientific journals and providing good opportunities for establishing international contacts. We would recommend that if $\mathrm{PhD}$ candidates notice that their supervisor(s) take little to no interest in publishing in international, scientific journals, that they take action on their own. The same holds true for establishing international and domestic networks. Inactivity on the part of $\mathrm{PhD}$ candidates and supervisors in this respect places $\mathrm{PhD}$ candidates in an outsider position. However, an inactive disposition on the part of the supervisor need not be the end of the matter. $\mathrm{PhD}$ candidates can take their own initiative to reach agreements with their supervisors about the above points.

Many doctoral recipients will in many cases, or at least initially, have to settle for temporary or fixed-term appointments. Results from our study suggest that Dutch doctoral programmes are not necessarily broad enough to provide doctoral recipients attractive employment options in both the public and private sector. To ensure the best employment opportunities are available, $\mathrm{PhD}$ candidates can take courses within their discipline that extend beyond the $\mathrm{PhD}$ research, can consider interdisciplinary research and can acquire teaching and research experience within or outside the research institute. $\mathrm{PhD}$ candidates are not alone in these matters. Organisations that represent $\mathrm{PhD}$ candidates (at the level of graduate schools or universities) can help by arranging mentor programmes between doctoral recipients and third and fourth-year $\mathrm{PhD}$ candidates. Alumni associations of doctoral recipients may be crucial in this regard.

\section{Supervisors}

Results from our research suggest that doctoral recipients believe supervisors have only moderate to low expectations in regards to $\mathrm{PhD}$ candidates acquiring teaching and research experience outside their research institute. While we are not arguing here that supervisors have a duty to secure a new job for their $\mathrm{PhD}$ candidates, the relationship between supervisors and $\mathrm{PhD}$ candidates is highly selective. Supervisors will likely try hard to arrange employment opportunities for their best $\mathrm{PhD}$ candidates. Whether supervisors take an active or a passive approach to their $\mathrm{PhD}$ candidates' post-graduation employment opportunities, supervisors can play an important role in making $\mathrm{PhD}$ candidates attractive job candidates in several respects, for example, helping them explore possibilities for gaining professional experience outside the institute. In addition, supervisors can play an important role in encouraging $\mathrm{PhD}$ candidates to consider follow-up research projects and can assist them in developing and submitting grant proposals during the $\mathrm{PhD}$ trajectory. Supervisors can also emphasize the importance of gaining teaching experience and can help prepare them professionally for this role, for example by allowing $\mathrm{PhD}$ candidates to undertake pedagogical training. Ideally, supervisors can provide assistance to their $\mathrm{PhD}$ candidate by help- 
ing them think about planning activities not directly related to their $\mathrm{PhD}$ thesis, such as gaining extra research experience. While these activities may not be directly related to their $\mathrm{PhD}$ work, such activities do not necessarily form a threat to timely $\mathrm{PhD}$ completion.

\section{Universities and graduate and research schools}

Our research (Sonneveld et al., 2010) suggests that few doctoral recipients felt that the institute where they were conducting their $\mathrm{PhD}$ research provided clear information about the labour market position of other graduates. It seems that, at a minimum, universities and graduate and research schools should gather and disseminate up-to-date labour market information to help prepare doctoral recipients for the labour market. Two options come to mind. Graduate and research schools can acquire more data about their doctoral graduates, for example, request annual updates about the employment of doctoral recipients. This will help inform $\mathrm{PhD}$ candidates about employment possibilities following graduation. Second, universities can bring their current $\mathrm{PhD}$ candidates in touch with doctoral alumni, possibly at annual gatherings or in a mentor programme. This not only facilitates mentoring, but could also lead to work or research experience with alumni, which would enhance the labour market qualifications of $\mathrm{PhD}$ candidates.

Moreover PhD candidates felt universities did little to prepare them for the labour market and few candidates make use of any university career service (Sonneveld et al., 2010). Universities would be well-placed to investigate why PhD candidates make so little use of university facilities. Do such facilities exist? Is there a lack of awareness among $\mathrm{PhD}$ candidates about these facilities? Clearly, if service career services are available but awareness of these services is low, than such services are likely to be ineffective. This is yet another area where $\mathrm{PhD}$ associations might pioneer change, for example, by designing and maintaining relevant career websites. However, initiatives such as these will gain considerable visibility in this field if they are embedded in a robust organisational (university) structure. For example, American universities have Career Information Centres; British PhD students can rely on their national organisation called Vitae (a national organisation championing the personal, professional, and career development of doctoral researchers and research staff in higher education institutions and research institutes). These initiatives offer examples for universities in other countries, which can then be tailored to suit national or local situations.

\section{Acknowledgements}

This project was financed by the Dutch Ministry of Education, Culture and Science and the Netherlands Centre for Graduate and Research Schools at Utrecht University. The first author was supported by a grant from the Netherlands organization for scientific research: NWO-VENI-45111-008. The authors would like to thank the Ministry of Education, Culture and Science, in particular Jan van Steen and Martine Warmerdam, for useful comments on the publication of our findings.

\section{References}

Academy of Finland. (2003). PhDs in Finland: Employment, placement and demand. Helsinki: Academy of Finland.

Austin, A. E. (2002). Preparing the next generation of faculty: Graduate school as socialization to the academic career. The Journal of Higher Education, 73(1), 94 - 122.

Berger, J., \& de Jonge, J. (2005). Rendement verkend. Beleidsgerichte studies Hoger onderwijs en Wetenschappelijk onderzoek, nr. 116. (Den Haag: SDU).

Bowen, W. G., \& Rudenstine, N. L. (1992). In pursuit of the Ph.D. Princeton: Princeton University Press. 
Bleiklie, I., \& Høstaker, R. (2004). Modernizing research training-education and science policy between profession, discipline and academic institution. Higher Education Policy, 17, 221-236.

CBS. (2010). CBS Statline. Centraal Bureau voor de Statistiek (Statistics Netherlands).

Dany, F., \& Mangematin, V. (2004). Beyond the dualism between lifelong employment and job insecurity: Some new career promises for young scientists. Higher Education Policy, 17, 201-220.

Dotzler, R. J., \& Koppel, R.. (1999). What sociologists do and where they do it. Sociological Practice, 1, 71-83.

EC. (2007). Key data on higher education in Europe. Brussels: European Commission.

Enders, C. K., \& Bandolos, D. L. (2001). The relative performance to full information maximum likelihood estimation for missing data in structural equation models. Structural Equation Modelling, 8, 430-457.

Enders, J. (2001). Academic staff in Europe. Changing contexts and conditions. Westport, Connecticut: Greenwood Press.

Enders, J. \& de Weert, E. (2004). Science, training and career: Changing modes of knowledge production and labour markets. Higher Education Policy, 17, 135-152.

EUROSTAT / UNESCO / OECD. (2006). Statistics on the careers of doctorate holders (CDH). Brussels: European Commission.

Fox, M. F., \& Stephan, P. E. (2001). Careers of young scientists: Preferences, prospects and realities by gender and field. Social Studies of Science, 31, 109-122; doi 10.1177/030631201031001006

Golde, C. M. (2000). Should I stay or should I go? Student descriptions of the doctoral attrition process. The Review of Higher Education, 23(2), 199 - 227.

Hersevoort, M., Rienstra, M., \& Ter Haar, D. (2007). Careers of doctorate holders 2005. Feasibility study and first results. Statistics Netherlands, Heerlen.

Hills, J. M., Robertson, G., Walker, R., Adey, M. A., \& Nixon, I. (2003). Bridging the gap between degree programme curricula and employability through implementation of work-related learning, Teaching in Higher Education, 8(2), 211-231

Hockey, J. (1991). The social science Ph.D.: A literature review. Studies in Higher Education, 16(3), 319333.

Hoffius, R., \& Surachno, S. (2006). Tussen wens en werkelijkheid: carrièreperspectieven van jonge onderzoekers. Eindrapport. [Between desire and reality: career prospects of young researchers. Final report] Research voor Beleid, Leiden.

Huisman, J., de Weert, E., \& Bartelse, J. (2002). Academic careers from a European perspective. The Journal of Higher Education, 73, 141-160.

Hulshof, M., Verrijt, A., \& Kruijthof, A. (1996). Promoveren en de arbeidsmarkt: ervaringen van de 'lost generation'.[Obtaining a PhD and the labor market experiences of the 'lost generation'] Beleidsgerichte Studies Hoger Onderwijs en Wetenschappelijk Onderzoek, $n r$. 43. (Den Haag: SDU).

Keijzer, B. S. C., \& Gordijn, E. H. (2000). Resultaten Arbeidsmarkt enquete Jonge Wetenschappers. [Results of the Labour market survey among Young Scientists]. University of Amsterdam, Amsterdam.

Knobil, E. (1996). Doctoral education in the biomedical sciences: Back to the future? Academic Medicine, , 871-875.

Lee, H-f, Miozzo, M., \& Laredo, P. (2010). Career patterns and competences of PhDs in science and engineering in the knowledge economy: The case of graduates from a UK research-based university. Research Policy, 37, 869-881.

Lovitts, B. E. (2008). The transition to independent research: Who makes it, who doesn't, and why. The Journal of Higher Education, 79(3), 296-325. 
Manathunga, C., Pitt, R., \& Critchley, C. (2009). Graduate attribute development and employment outcomes: Tracking PhD graduates. Assessment \& Evaluation in Higher Education, 34, 91-103.

Mastekaasa, A. (2005). Gender differences in educational attainment: The case of doctoral degrees in Norway. The British Journal of Sociology of Education, 26, 375-394.

Ministry of General Affairs. (2010). Coalition agreement (Regeerakkoord). Ministry of General Affairs: The Hague, the Netherlands.

Musselin, C. (2004). Towards a European academic labour market? Some lessons drawn from empirical studies on academic mobility. Higher Education, 48, 55-78.

Muthen, L. K., \& Muthen, B. O. (2007). Mplus: Statistical analysis with latent variables: User's guide. Los Angeles, CA: Mutheen \& Muthen.

Nerad, M. (2004). The PhD in the US: Criticism, facts and remedies. Higher Education Policy, 17, 183200.

NRC. (2010). Gender differences at critical transitions in the careers of science, engineering, and mathematics faculty. Committee on Gender Differences in the Careers of Science, Engineering, and Mathematics Faculty; Committee on Women in Science, Engineering, and Medicine; Committee on National Statistics; National Research Council. Washington, D.C.

Oost, H., \& Sonneveld, H. (2006). Het promotiesucces van de Nederlandse onderzoekscholen. Afsluiting van een drieluik. [The promotion success of the Dutch research schools. Closure of a triptych.]. Beleidsgerichte Studies Hoger Onderwijs en Wetenschappelijk Onderzoek, nr. 123. (Den Haag: SDU).

Rennie, D. L., \& Brewer, L. (1987). A grounded theory of thesis blocking. Teaching of Psychology, 14(1), $10-16$.

Sonneveld, H., Yerkes, M., \& Van de Schoot, R. (2010). Ph.D. Trajectories and labour market mobility. A survey of recent doctoral recipients at four universities in the Netherlands. Utrecht: Nederlands Centrum voor de Promotieopleiding / IVLOS. Accessible at http://phdcentre.org/nl/publicaties/

Sadlak, J. (2004). Doctoral studies and qualifications in Europe and the United States: Status and prospects. UNESCO, Bucharest.

Sclater, K., Rudd, E., Morrison, E., Picciano, J. \& Nerad, M. (2008). After the degree: Recent history PhDs weigh in on careers and graduate school. Center for Innovation and Research in Graduate Education, University of Washington, Seattle.

Siegfried, J. J., \& Stock, W. A. (1999). The labor market for new Ph.D. economists. The Journal of Economic Perspectives, 13, 115-134.

Statistics Netherlands. (2011). Careers of doctorate holders (CDH) 2009. The Hague.

van der Neut, A. C., \& de Jonge, J. F. M. (1993). De meerwaarde van een promotie. Een vergelijkende studie van de loopbanen van gepromoveerde en niet-gepromoveerde academici.[ The added value of a promotion. A comparative study of the careers of doctoral and pre-doctoral scholars]. The Ministry of Education and Sciences, The Hague.

UK Grad Programme. (2004). What do PhDs do? 2004 analysis of first destinations for PhD graduates. Cambridge: UK Grad Programme.

Yerkes, M., van de Schoot, R., \& Sonneveld, H. (2012). Who are the job seekers? Explaining unemployment among doctoral recipients. International Journal of Doctoral Studies, 7, 153-166. Retrieved from http://ijds.org/Volume7/IJDSv7p153-166Yerkes346.pdf 


\section{Biographies}

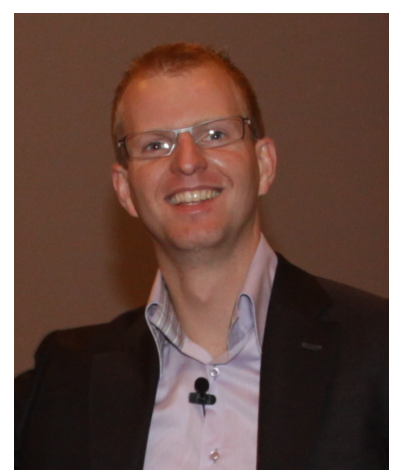

Rens van de Schoot graduated cum laude for the research master Development and Socialization of Children and Adolescents. He obtained his $\mathrm{PhD}$ (cum laude) about Bayesian statistics at the department of Methods and Statistics. Currently, he is assistant professor at Utrecht University and extra-ordinary professor at the North-West University in South-Africa. Rens is also co-editor for the European Journal of Developmental Psychology and president of the young researchers union of the European Association of Developmental Psychology. Furthermore, Rens lectures Mplus related courses all over the world and he coordinates all the Mplus-courses given at UtrechtUniversity, including a three week summer school. Finally, Rens organizes international Mplus users meetings

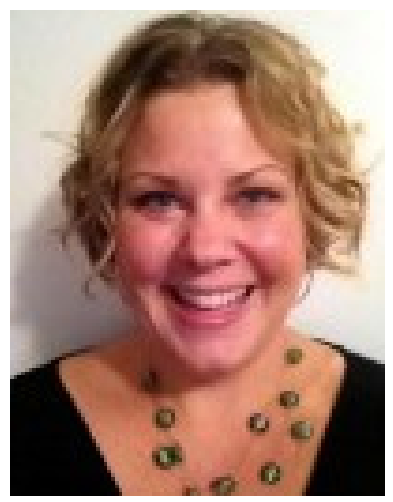

Mara Yerkes is a Senior Research Fellow at the Institute for Social Science Research (ISSR) at the University of Queensland. Yerkes has published extensively on social and employment policy, comparative welfare states, the combination of work and care, and more recently on tertiary educational outcomes, in particular gender differences. She is the author of Transforming the Dutch Welfare State: Social risks and corporatist reform (The Policy Press) and co-editor of The Transformation of Solidarity: Changing Risks and the Future of the Welfare State (Amsterdam University Press).

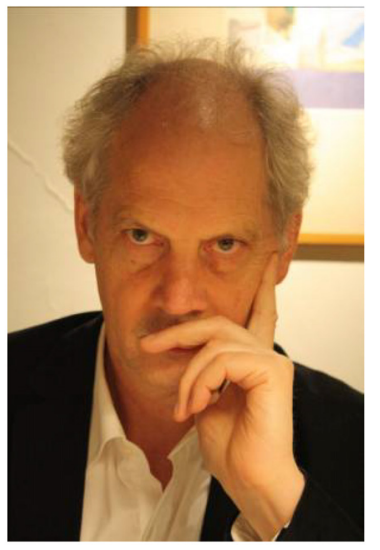

Hans Sonneveld is a sociologist by training, with a $\mathrm{PhD}$ in the social sciences \& science dynamics. From 1988 - 2006 he was managing director of one of the first Dutch graduate schools, the Amsterdam School for social Science Research. In 1996, he published his book PhD supervisors, PhD students and the Academic Selection. In 2006, together with his colleague Heinze Oost $(\dagger 2008)$, Hans Sonneveld founded the Netherlands Centre for Research and Graduate Schools, a meeting place for all those who work on the development of the Dutch $\mathrm{PhD}$ system. He has been investigating the careers of the PhD students who have defended their dissertation in the Netherlands, the interest of PhD students in contributing to secondary education and the completion and attrition rates of $\mathrm{PhD}$ subsidies by the Netherlands Organization for Scientific Research (NWO). At the individual level of teaching and coaching, Hans Sonneveld provides courses to $\mathrm{PhD}$ students (How

to write your PhD Proposal). Hans also trains and supervises beginning and more experienced PhD supervisors in many fields, including Informatics, Psychology, Law, Arts, Meteorology, Physics and Educational Sciences. 